Gut, 1967, 8, 592

\title{
Effect of intravenous calcium administration on gastric secretion of acid and pepsin in man
}

\author{
R. A. SMALLWOOD \\ From the University of Melbourne Department of Medicine, \\ The Royal Melbourne Hospital, Melbourne, Australia
}

EDITORIAL COMMENT An acute rise in the serum calcium increases acid and pepsin secretion and this effect is abolished by vagotomy.

Despite reports of the association of hyperparathyroidism and peptic ulcer (Rogers, Keating, Morlock, and Barker, 1947; Black, 1953; Hellström, 1959), the relationship cannot be accepted as proven (Ostrow, Blanshard, and Gray, 1960). The issue is clouded by the differing figures given for the incidence of peptic ulcer in the community (Ivy, Grossman, and Bachrach, 1950; Jones, 1959; Ellison, Abrams, and Smith, 1959), the common occurrence of dyspeptic symptoms in patients with hyperparathyroidism who have no ulcer (Gutman, Swenson, and Parsons, 1934; St. Goar, 1957), and the association of parathyroid and pancreatic adenomas, where peptic ulceration may be related to the latter.

This apparent association between hyperparathyroidism and peptic ulcer raises the question of a possible relationship between serum calcium levels and gastric function. Previous studies on the effects of parathyroidectomy on gastric secretion in patients with hyperparathyroidism have produced conflicting results (Donegan and Spiro, 1960; Ward, Adesola, and Welbourn, 1964; Barreras and Donaldson, 1966). Hypercalcaemia produced by intravenous calcium administration in humans has been found, with one exception (Fikry and Dorry, 1964), to lead to an increase in gastric secretion (Donegan and Spiro, 1960; Barreras and Donaldson, 1966; Sereghy and Gyurkovich, 1927; Ottenjann. Widmaier, and Demling, 1963; Fillastre, Blaise, Bernier, and Richet, 1963; Murphy, Goldstein, Boyle, and Ward, 1966). However, a detailed examination of the pattern of rise and fall of serum calcium and gastric secretion has not been made. The demonstration of a parallel relationship between the serum calcium and gastric secretion would be an essential prerequisite for the appli- cation of the findings in these acute experiments to the clinical situation.

This study was undertaken to clarify the relationship between serum calcium levels and gastric secretion following intravenous calcium, and to investigate the mechanism whereby intravenous calcium produced its apparent secretagogue effect.

MATERIALS AND METHODS

Details of the 19 patients studied and of the schedules of calcium administration are summarized in Table $\mathbf{I}$. Calcium was administered either by intravenous infusion of $4 \%$ calcium gluconate in normal saline for one or two hours, or as an intravenous injection of $10 \%$ calcium gluconate, given over five to eight minutes. Subject 6 received, instead of $4 \%$ calcium gluconate, an equimolar solution of calcium chloride. The total amount of calcium given in each infusion ranged in the various studies from 180 to $864 \mathrm{mg}$. Indwelling needles in each arm were used for infusion and blood sampling.

Gastric juice was collected through a nasogastric tube, passed under radiological control so that the tip lay in the most dependent point in the stomach. Care was taken to ensure that there was no excess length of tube in the stomach. Radiological screening at the end of the studies confirmed that the tube had not changed position. After initial emptying of the stomach, secretions were aspirated continuously by hand, beginning no earlier than an hour after the passage of the tube. Subjects were studied in a semirecumbent position with slight changes at frequent intervals to try to ensure that no residual pools of secretion were missed. The gastric juice collected in the initial hour was designated the 'resting secretion'. In subjects given a calcium infusion, gastric secretions were collected over hourly or haif-hourly periods, for up to five hours. In those given calcium injections, the resting secretion was compared with that in the hour 
TABLE I

DETAILS OF SUBJECTS AND METHODS OF CALCIUM ADMINISTRATION

\begin{tabular}{|c|c|c|c|c|c|c|}
\hline \multirow[t]{2}{*}{ Subject } & \multirow[t]{2}{*}{$\begin{array}{l}\text { Age } \\
\text { (years) }\end{array}$} & \multirow[t]{2}{*}{$\operatorname{Sex}$} & \multirow[t]{2}{*}{$\begin{array}{l}\text { Clinical } \\
\text { Diagnosis }\end{array}$} & \multicolumn{2}{|c|}{$\begin{array}{l}\text { Calcium Infusion } \\
\text { (mg. of calcium per } \\
\text { kg. body weight) }\end{array}$} & \multirow[t]{2}{*}{$\begin{array}{l}\text { Calcium Injection } \\
(\mathrm{ml} \text {. of } 10 \% \text { calcium } \\
\text { gluconate })\end{array}$} \\
\hline & & & & First Hour & Second Hour & \\
\hline 1 & 22 & $\mathbf{M}$ & Normal & 9 & $4 \cdot 5$ & \\
\hline 2 & 35 & $\mathbf{M}$ & Duodenal ulcer & 9 & $4 \cdot 5$ & \\
\hline 3 & 22 & $\mathbf{M}$ & Normal & 9 & nil & \\
\hline 4 & 24 & $\mathbf{M}$ & Hyperparathyroidism & 7 & nil & \\
\hline 5 & 52 & $\mathbf{M}$ & Duodenal ulcer & 9 & nil & \\
\hline $6^{1}$ & 60 & $\mathbf{M}$ & Duodenal ulcer & 9 & nil & \\
\hline 7 & 44 & $\mathbf{M}$ & Duodenal ulcer & & & 20 \\
\hline 8 & 23 & $\mathbf{F}$ & Duodenal ulcer & & & 20 \\
\hline 9 & 61 & $\mathbf{M}$ & Duodenal ulcer & See text & & \\
\hline 10 & 42 & $\mathbf{F}$ & Duodenal ulcer & & & See text and Fig. 2 \\
\hline $11^{2}$ & 42 & $\mathbf{M}$ & Duodenal ulcer & 9 & nil & \\
\hline $12^{2}$ & 53 & $\mathbf{F}$ & $\begin{array}{l}\text { Duodenal ulcer and } \\
\text { hyperparathyroidism }\end{array}$ & $6^{8}$ & nil & \\
\hline $13^{2}$ & 53 & $\mathbf{M}$ & Duodenal ulcer & & & 20 \\
\hline $14^{2}$ & 60 & $\mathbf{M}$ & Duodenal ulcer & & & 20 \\
\hline $15^{2}$ & 31 & $\mathbf{M}$ & Duodenal ulcer & & & 20 \\
\hline $16^{2}$ & 46 & $\mathbf{F}$ & Cholelithiasis & & & 20 \\
\hline $17^{2}$ & 64 & $\mathbf{F}$ & Cholelithiasis & & & 20 \\
\hline $18^{2}$ & 43 & $\mathbf{M}$ & Duodenal ulcer & & & 20 \\
\hline $19^{2}$ & 50 & $\mathbf{F}$ & Duodenal ulcer & $6^{3}$ & nil & \\
\hline
\end{tabular}

following injections of calcium, saline, or betazole hydrochloride (Histalog).

Blood pressure and electrocardiographic recordings were taken in those subjects to whom larger amounts of calcium were given. Pulse rates were recorded throughout all studies.

Blood for calcium estimations was taken without stasis at the beginning of each study, and at regular intervals thereafter. Serum calcium levels were estimated by an automated fluorimetric method (Martin and Baird, 1965).

The volume and $p \mathrm{H}$ of all gastric juice samples were measured. The $p \mathrm{H}$ was measured directly in a Metrohm $p \mathrm{H}$ meter with a glass electrode. Five ml. aliquots were titrated to $p \mathrm{H} 7$ with $0 \cdot 1 \mathrm{~N} \mathrm{NaOH}$. The concentration and total hydrogen ion content of each sample were derived from these results.

Pepsin activity in $1 \mathrm{ml}$. of each sample was measured by the method of Anson (1938), using beef haemoglobin as substrate. The pepsin unit is defined as the quantity of enzyme which liberates $8 \times 10^{-4} \mathrm{mEq}$. of tyrosine in $5 \mathrm{ml}$. of trichloracetic acid filtrate in 10 minutes at $37^{\circ} \mathrm{C}$.

The study was divided into three main sections:

1 GASTRIC SECRETORY RESPONSE TO INTRAVENOUS CALCIUM (sUBJECTS 1-10) Subjects 1-6 received infusions of calcium and subjects 7 and 8 intravenous calcium injections. Subject 9 received two consecutive calcium infusions, comprising $7 \mathrm{mg}$. of calcium per $\mathrm{kg}$. body weight and $5 \mathrm{mg}$. calcium per $\mathrm{kg}$. body weight over half an hour respectively, given an hour apart. Subject 10 received two consecutive injections of $10 \%$ calcium. gluconate, of $20 \mathrm{ml}$. and $16 \mathrm{ml}$. respectively, given one and a half hours apart.

Saline controls were used in subjects 1-8. An equal volume of saline was administered in an identical manner to the calcium in each subject (Table I). Calcium and saline were administered in a randomized sequence.

2 MODIFICATIONS BY ATROPINE OF THE GASTRIC SECRETORY RESPONSE TO INTRAVENOUS CALCIUM Subjects 11 and 12 each received two identical calcium infusions on consecutive days. However, on the second day, calcium infusion was preceded by cholinergic blockade with atropine. Atropine sulphate, $2.4 \mathrm{mg}$., was diluted in $20 \mathrm{ml}$. normal saline, and initially $0.6 \mathrm{mg}$. was given intravenously followed by increments of $0.3 \mathrm{mg}$. until there was no further rise in pulse rate. Subject 11 received a total of $2.1 \mathrm{mg}$. and subject $12,1.8 \mathrm{mg}$. over $20-25$ minutes.

3 EFFECT OF VAGOTOMY AND CHOLECYSTECTOMY ON THE GASTRIC SECRETORY RESPONSE TO INTRAVENOUS CALCIUM (SUBJECTS 13-19) Five subjects who underwent vagotomy and a drainage operation were given intravenous calcium followed by subcutaneous Histalog. Pyloroplasty was the drainage procedure employed, except in subject 13, who had a gastroenterostomy. Subjects 13, 14, and 15 were studied before and after operation; subjects 18 and 19 post-operatively only. Subject 18 was studied on two occasions, on the second day receiving an additional constant infusion of methacholine (Mecholyl) $(0.1 \mathrm{mg} . / \mathrm{minute})$. Two others, subjects 16 and 17, were studied before and after cholecystectomy. These served as controls in that they underwent 
a comparable upper abdominal operation. Histalog, $50 \mathrm{mg}$., was given as a single subcutaneous injection in all studies in subjects undergoing operation. PostHistalog secretion was collected as four 15-minute samples, so that the pattern of response could be assessed. The completeness of vagotomy was confirmed by insulin tests. The studies in these subjects were carried out two weeks post-operatively.

\section{RESULTS}

Following calcium infusion, the serum calcium rose by $0.5-4.7 \mathrm{mg} . / 100 \mathrm{ml}$. Following calcium injection the rise was $0 \cdot 5-2 \cdot 8 \mathrm{mg}$. $/ 100 \mathrm{ml}$.

As the changes in acid and pepsin secretion proved to be similar in the early studies, only acid secretion was considered in subjects 14-19, in whom there were often insufficient volumes of gastric juice available for both acid and pepsin estimations.

GASTRIC SECRETORY RESPONSE TO INTRAVENOUS CALCIUM In subjects 1-6, the hourly acid output increased during, and in two subjects in the hour following, calcium infusion. It reached a maximum in the first or second hour and returned to around resting levels by the third or fourth hour. The pattern was consistent in all subjects, including subject 6, who received calcium chloride. A typical result is shown in Figure 1. Parallel change occurred in pepsin output. With saline infusion, increases in hourly hydrogen ion and pepsin output also occurred. However, they were much smaller than with calcium infusions and the patterns of rise and fall were irregular. Indeed, subject 3 remained achlorhydric with saline, but achieved a total hydrogen ion output of $1.4 \mathrm{mEq}$. with calcium.
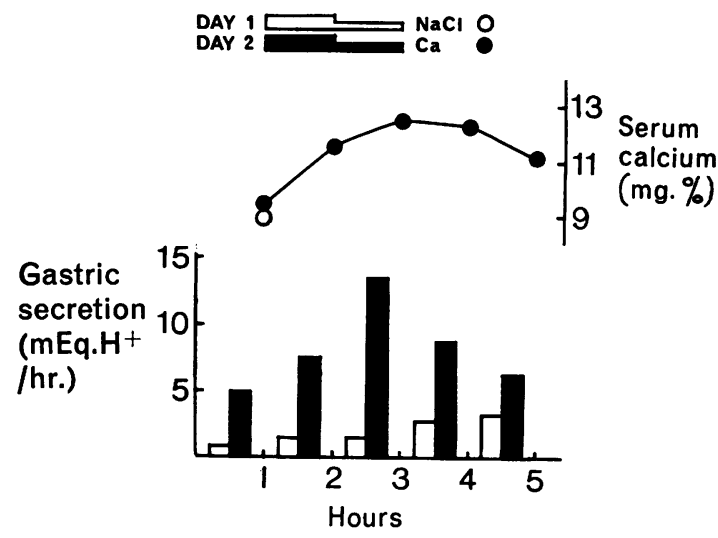

FIG. 1. Changes in gastric acid secretion and serum calcium in subject 1. Day 1: saline infusion. Day 2: calcium infusion.
Table II expresses the increased secretion as either the mean or peak hourly acid and pepsin output above resting levels over the four hours after the start of the infusion. In every case, the calcium figure is higher than the control, and paired t tests show that the differences are significant. This was also true for pepsin secretion.

\section{TABLE II}

INCREASE IN ACID SECRETION FOLLOWING INFUSIONS OF $4 \%$ CALCIUM GLUCONATE OR $0.9 \% \mathrm{NaCl}^{1}$

\begin{tabular}{lllll}
$\begin{array}{l}\text { Subject } \\
\text { Mean Increase in } \\
\end{array}$ & $\begin{array}{l}\text { Hourly Acid Secretion } \\
\text { (mEq./hour) }\end{array}$ & $\begin{array}{l}\text { Peak Increase in } \\
\text { Hourly Acid Secretion } \\
\text { (mEq./hour) }\end{array}$ \\
\cline { 2 - 5 } & $\mathrm{NaCl}$ & Calcium & $\mathrm{NaCl}$ & Calcium \\
\hline 1 & 1.4 & 6.5 & 2.3 & 8.5 \\
2 & 1.7 & 7.2 & 2.5 & 10.6 \\
3 & nil & 0.5 & nil & 1.5 \\
4 & 1.2 & 2.0 & 1.4 & 3.3 \\
5 & 0.9 & 7.7 & 2.0 & 8.9 \\
& $0.025>\mathrm{P}>0.0125$ & $0.0125>\mathrm{P}>0.01$
\end{tabular}

1 Values given represent the increase in acid secretion over the four hours after starting the infusion.

Despite a tendency for the resting secretion to be slightly higher on calcium than on control days, the differences were not significant $(P>0 \cdot 2)$. In subjects 1-6 calcium infusion increased serum calcium levels by 1.1 to $4.7 \mathrm{mg}$. $/ 100 \mathrm{ml}$. In every case the serum calcium level remained elevated for seven to eight hours, in contrast with the acid and pepsin output, which returned to around resting levels within three to four hours.

Saline infusions over one to two hours in three

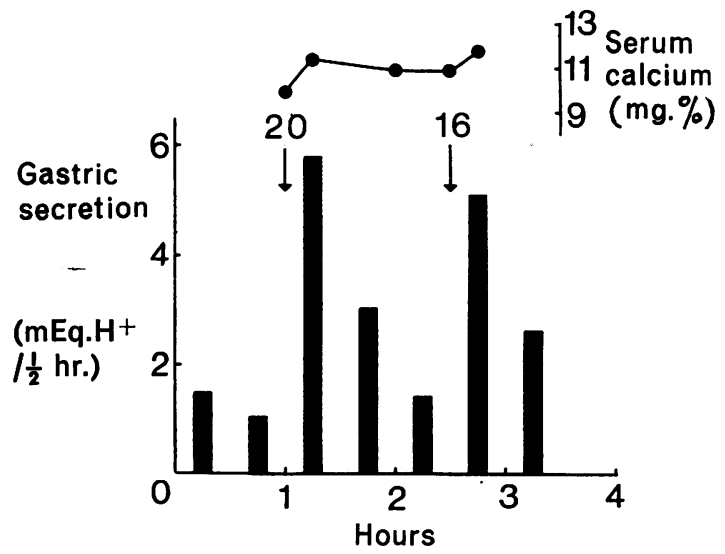

FIG. 2. Changes in gastric acid secretion and serum calcium following intravenous injections of $20 \mathrm{ml}$. and $16 \mathrm{ml}$. of $10 \%$ calcium gluconate (subject 10 ). 
DAY 1

DAY 2

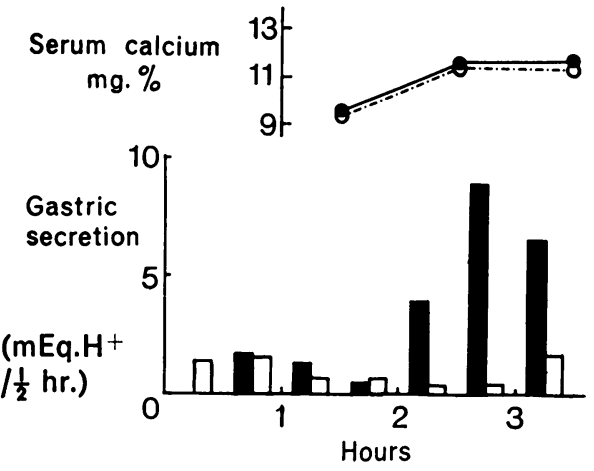

FIG. 3. Changes in gastric acid secretion and serum calcium in subject 11. Day 1: calcium infusion. Day: 2 calcium infusion preceded by intravenous atropine.

subjects were found to have no effect on the serum calcium concentrations.

Intravenous injection of $20 \mathrm{ml}$. of $10 \%$ calcium gluconate produced an increase in acid and pepsin output to about double resting levels. Saline injections, however, did not produce any increase in gastric secretion.

In subject 9, a second infusion of calcium was given before the secretion rate had started to fall. In subject 10 , a second injection was given when the secretion rate had fallen to resting levels, but while the serum calcium was still elevated (Fig. 2). In both cases, a second sharp rise in secretion of acid and pepsin occurred.

MODIFICATION OF GASTRIC SECRETORY RESPONSE TO INTRAVENOUS CALCIUM BY ATROPINE Cholinergic blockade with atropine completely suppressed the rise in acid and pepsin output produced by calcium infusion in the two subjects studied. Figure 3 illustrates the changes in acid output in subject 11 .

EFFECT OF VAGOTOMY AND CHOLECYSTECTOMY ON THE GASTRIC SECRETORY RESPONSE TO INTRAVENOUS CALCIUM AND SUBCUTANEOUS HISTALOG Before vagotomy, the injection of $180 \mathrm{mg}$. of calcium over five to eight minutes approximately doubled the acid output. No increase at all was detectable after operation (Table III). There was a post-operative reduction of 30 to $60 \%$ in post-Histalog secretion, and of 40 to $70 \%$ in the resting secretion.

However, responses to calcium and Histalog were unchanged before and after cholecystectomy.

Table IV shows the effect of a constant infusion of Mecholyl on the secretory responses to calcium
TABLE III

EFFECT OF CALCIUM AND HISTALOG INJECTIONS ON GASTRIC ACID SECRETION BEFORE AND AFTER VAGOTOMY AND A DRAINAGE PROCEDURE

\begin{tabular}{|c|c|c|c|c|}
\hline \multirow{2}{*}{$\begin{array}{l}\text { Subject } \\
\text { No. }\end{array}$} & \multirow{2}{*}{$\begin{array}{l}\text { Time } \\
\text { (hours) }\end{array}$} & \multirow[t]{2}{*}{ Injection } & \multicolumn{2}{|c|}{ Acid Output (mEq./hour) } \\
\hline & & & Preoperative & Postoperative \\
\hline 13 & $\begin{array}{l}1 \\
2 \\
3\end{array}$ & $\begin{array}{l}\text { Nil } \\
\text { Calcium } \\
\text { Histalog }\end{array}$ & $\begin{array}{l}10 \cdot 4 \\
20 \cdot 0 \\
62 \cdot 0\end{array}$ & $\begin{array}{r}4 \cdot 5 \\
2 \cdot 6 \\
43 \cdot 5\end{array}$ \\
\hline 14 & $\begin{array}{l}1 \\
2 \\
3\end{array}$ & $\begin{array}{l}\text { Nil } \\
\text { Calcium } \\
\text { Histalog }\end{array}$ & $\begin{array}{r}2 \cdot 1 \\
4.9 \\
30.0\end{array}$ & $\begin{array}{r}0.6 \\
0.2 \\
11.4\end{array}$ \\
\hline 15 & $\begin{array}{l}1 \\
2 \\
3\end{array}$ & $\begin{array}{l}\text { Nil } \\
\text { Calcium } \\
\text { Histalog }\end{array}$ & $\begin{array}{r}5.0 \\
10.0 \\
28.0\end{array}$ & $\begin{array}{r}3.0 \\
3 \cdot 1 \\
16.8\end{array}$ \\
\hline
\end{tabular}

TABLE IV

EFFECT OF A CONTINUOUS INFUSION OF MECHOLYL ON GASTRIC SECRETORY RESPONSE TO CALCIUM AND HISTALOG INJECTIONS IN A SUBJECT WITH VAGOTOMY AND PYLOROPLASTY

\begin{tabular}{|c|c|c|c|c|}
\hline \multirow{2}{*}{$\begin{array}{l}\text { Subject } \\
\text { No. }\end{array}$} & \multirow{2}{*}{$\begin{array}{l}\text { Time } \\
\text { (hours) }\end{array}$} & \multirow[t]{2}{*}{ Injection } & \multicolumn{2}{|c|}{ Acid Output (mEq./hour) } \\
\hline & & & $\begin{array}{l}\text { Without } \\
\text { Mecholyl }\end{array}$ & $\begin{array}{l}\text { With } \\
\text { Mecholyl }\end{array}$ \\
\hline 18 & $\begin{array}{l}1 \\
2 \\
3\end{array}$ & $\begin{array}{l}\text { Nil } \\
\text { Calcium } \\
\text { Histalog }\end{array}$ & $\begin{array}{r}2 \cdot 5 \\
2 \cdot 7 \\
21 \cdot 7\end{array}$ & $\begin{array}{l}14 \cdot 0 \\
13 \cdot 1 \\
30 \cdot 5\end{array}$ \\
\hline
\end{tabular}

and Histalog injections after vagotomy (subject 18). With Mecholyl the response to Histalog increased by $40 \%$. However, no response to calcium occurred either with or without Mecholyl.

In subject 19, to whom a larger amount of calcium was administered so that the serum calcium rose by $3.6 \mathrm{mg} . / 100 \mathrm{ml}$., there was still no gastric secretory response to calcium after vagotomy (Table V).

TABLE V

EFFECT OF CALCIUM INFUSION AND HISTALOG INJECTION ON GASTRIC ACID SECRETION IN A SUBJECT WITH VAGOTOMY AND PYLOROPLASTY

\begin{tabular}{|c|c|c|c|c|}
\hline $\begin{array}{l}\text { Subject } \\
\text { No. }\end{array}$ & $\begin{array}{l}\text { Sample } \\
\text { (half hourly } \\
\text { collections) }\end{array}$ & Infusion & $\begin{array}{l}\text { Serum }^{1} \\
\text { Calcium } \\
(\mathrm{mg} . / 100 \mathrm{ml} .)\end{array}$ & $\begin{array}{l}\text { Acid Output } \\
\text { (mEq./1 hour) }\end{array}$ \\
\hline 19 & $\begin{array}{l}1 \\
2 \\
3 \\
4 \\
5 \\
\\
6\end{array}$ & $\begin{array}{l}\text { Nil } \\
\text { Calcium } \\
\text { Nil } \\
\text { Nil } \\
\text { Histalog } \\
\text { injection } \\
\text { Nil }\end{array}$ & $\begin{array}{r}8 \cdot 5 \\
12 \cdot 1\end{array}$ & $\begin{array}{l}\text { Nil } \\
\text { Nil } \\
\text { Nil } \\
\text { Nil } \\
\\
3 \cdot 2 \\
5 \cdot 9\end{array}$ \\
\hline
\end{tabular}

1 Blood for serum calcium estimations taken at the end of the corresponding half-hour period. 


\section{DISCUSSION}

In every subject studied, except in the special circumstances discussed below, intravenous administration of calcium, either as gluconate or chloride, led to a rise in the output of acid and pepsin above the resting secretion. This result agrees with the findings of most previous authors (Donegan and Spiro, 1960; Barreras and Donaldson, 1966; Sereghy and Gyurkovich, 1927; Ottenjann et al., 1963; Fillastre et al., 1963; Murphy et al., 1966), but not those of Fikry and Dorry (1964), who found that calcium inhibited both basal and histamine-stimulated secretion. Fikry and Dorry administered calcium by repeated intravenous injections, in doses equivalent to $40 \mathrm{ml}$. of $10 \%$ calcium gluconate, whereas the other authors used relatively slow infusions. In the present study, both modes of administration were used. Single injections of $20 \mathrm{ml}$. of $10 \%$ calcium gluconate were found to produce nausea or faintness unless given slowly over five to eight minutes. When these symptoms occurred, gastric secretion was profoundly inhibited and studies in several subjects were stopped for this reason. Fikry and Dorry did not specify the rate of injection, nor did they mention whether any subjective effects were produced. This inhibitory effect of injecting calcium too rapidly may explain the discrepancy. Whereas most studies in man show that parenteral calcium leads to an increase in gastric secretion, in pigeons and various canine preparations, parenteral calcium has been found to inhibit gastric secretion (Ward et al., 1964; Cowgill and Rakieten, 1930; Babkin, Komarov, and Komarov, 1940; Grant, 1941; Mahfouz and Koskowski, 1959). However, in addition to possible species differences, the methods used in these studies have varied and are not strictly comparable with those used here.

The infusion experiments clearly showed that the secretory changes did not parallel the serum calcium levels. Although a sharp rise in secretion occurred with the acute rise in serum calcium, this response had disappeared by the third or fourth hour despite calcium levels being raised for seven to eight hours. A possible explanation would be an exhaustion of the response due to failure of the target organ, in this case the gastric parietal cells. That this is not the case is shown by subjects 9 and 10 , in whom a second administration of calcium produced a prompt gastric response. A more likely explanation is that the increased gastric secretion is not directly related to the actual serum calcium level, but rather to the sharp rise in serum calcium following an acute calcium load. Certainly, in no subject could any correlation be demonstrated be- tween the level of serum calcium and the output of acid and pepsin.

No conclusions can be drawn from the present study about the quantitative relationships between the dose of calcium, the rise in serum calcium levels, and the increase in gastric secretion. The relationships were not explored, chiefly because of the hazards involved with larger doses of calcium.

The effects of venepuncture and passing a nasogastric tube were minimized in the infusion experiments by carrying out these procedures at least 30 to 45 minutes before the study began. However, venepuncture was performed during many of the injection experiments. Calcium injections always produced an increase in gastric secretion, whether administered by direct venepuncture or through an indwelling needle. Saline administered by venepuncture did not increase gastric secretion. Therefore it is considered that venepuncture did not contribute to the rise in gastric secretion following calcium injection.

The circulatory and electrocardiographic changes observed during this study have been reported in detail (Smallwood, 1967). As a result of $T$ wave changes observed in subjects 1 and 2 , the dose of calcium administered in later studies was reduced.

A marked sinus bradycardia with sinus arrhythmia occurred with calcium administration in all subjects. Previous authors have concluded that this effect of intravenous calcium is due to vagal stimulation (Hoff and Nahum, 1937; Clarke, 1941; Boen, Leijnse, and Gerbrandy, 1962). Furthermore, in the infusion experiments, the increase in gastric secretion closely paralleled the development of the bradycardia, both indices returning to resting levels by the third or fourth hour. This suggested that the effect on the gastric mucosa might also be mediated by vagal stimulation. The complete abolition of the gastric secretory response to calcium by atropine or vagotomy, together with the abolition of the bradycardia by atropine, strongly supported this suggestion.

It is appreciated that both atropine and vagotomy will reduce the gastric response to various secretagogues, due possibly to the 'non-specific removal of a background of permissive cholinergic activity' (Payne and Kay, 1962). If this were the sole mechanism operating in the present study, a reduction of the same order as was seen in the resting and postHistalog secretion would be expected in the response to calcium. However, in none of the eight studies performed after cholinergic blockade was any response to calcium detectable.

The specificity of the effect of vagotomy in abolishing the secretory response to calcium was confirmed by the failure of Mecholyl, while restoring 
the 'permissive background of cholinergic activity', to restore the response to calcium. This finding indicates that calcium acts by stimulating the vagus at some preganglionic site. Whether it acts reflexly, or by stimulating the vagal centres in the brain stem (c.f. insulin), or by facilitating the release of acetylcholine at preganglionic vagal nerve endings (Carpenter and Rand, 1965; del Castillo and Katz, 1954) has yet to be defined.

The normal pattern of response to Histalog which was obtained in the post-vagotomy studies makes it unlikely that the absence of a response to calcium was due to incomplete collections of gastric secretions.

Incomplete or bile-contaminated collections were readily apparent, and occurred in several postoperative studies. Taken with those subjects who showed side effects either with calcium or from the presence of the nasogastric tube, over a third of the studies undertaken had to be discarded. Cholecystectomy did not alter the response to calcium so that the lack of response after vagotomy cannot be due to a non-specific effect of upper abdominal surgery.

The present study concurs with most of the previous work in humans on the effect of intravenous calcium on gastric secretion. However, by examining the mechanism of this effect in more detail, and its relationship to the changes in serum calcium levels, this study has underlined the doubtful validity, tacitly assumed by some in the past, of drawing inferences from the results of this acute experimental model and applying them to hyperparathyroidism. The effects of acute and chronic hypercalcaemia on the electrocardiogram differ markedly. The same is true of changes in renal function, where the acute rise in serum calcium superimposes additional changes to those associated with longstanding hypercalcaemia (Clarke, 1941 ; Freedman, Moulton, and Spencer, 1958; Gill and Bartter, 1961; Bronsky, Dubin, Waldstein, and Kushner, 1961). It may well be that the same situation obtains with hypercalcaemia and gastric secretion.

\section{SUMMARY AND CONCLUSIONS}

The intravenous administration of calcium to human subjects produced an increase in the gastric secretion of acid and pepsin.

The relationship of this increase and subsequent decrease in secretion to the changes in serum calcium levels indicated that the acute rise in serum calcium was probably the stimulus rather than the maintained supranormal calcium level.

Marked bradycardia with sinus arrhythmia occurred following intravenous calcium, and the changes in pulse rate were inversely related to the rise and fall in the gastric secretion. Both the bradycardia and the secretory response to calcium were abolished by atropine. Vagotomy, while reducing resting and post-Histalog secretion by $30-70 \%$, abolished the response to calcium. This response was not restored after vagotomy either by a larger infusion of calcium, or by a concurrent infusion of Mecholyl. These findings indicate that intravenous calcium causes increased gastric secretion primarily by vagal stimulation.

The validity of applying the findings in the acute hypercalcaemia of this experimental model to the longstanding hypercalcaemia of hyperparathyroidism is questioned.

I am indebted to Professor R. R. H. Lovell for continued encouragement and guidance, and to Dr. J. R. E. Fraser, Dr. R. A. Melick, and Professor A. E. Doyle for much helpful advice.

I am grateful to Dr. Cameron Baird, of the Biochemistry Department of the Royal Melbourne Hospital, for performing the serum calcium determinations, and to Professor W. S. C. Hare for making radiological facilities available.

Finally, I should like to thank Pam Clarke for her invaluable technical assistance.

\section{REFERENCES}

Anson, M. L. (1938). The estimation of pepsin, trypsin, papain, and cathepsin with haemoglobin. J. gen. Physiol., 22, 79-89.

Babkin, B. P., Komarov, O., and Komarov, S. A. (1940). The effect of activated ergosterol and of parathyroid hormone on gastric secretion in the dog. Endocrinology, 26, 703-715.

Barreras, R. F., and Donaldson, R. M. Jr. (1966). Gastric secretion during hypercalcaemia in man. Gastroenterology, 50, 6, 88 .

Black, B. M., (1953). Hyperparathyroidism, p. 50. Thomas, Springfield, Ill.

Boen, S. T., Leijnse, B., and Gerbrandy, J. (1962). Influence of serum calcium concentration on QT-interval and circulation. Clin. chim. Acta, 7, 432-436.

Bronsky, D., Dubin, A., Waldstein, S. S., and Kushner, D. S. (1961) Calcium and the electrocardiogram, II. The electrocardiographic manifestations of hyperparathyroidism and of marked hypercalcaemia from various other etiologies. Amer. J. Cardiol., 7, 833-839.

Carpenter, F. G., and Rand, S. A. (1965). Relation of acetylcholine release to responses of the rat urinary bladder. J. Physiol. (Lond.), 180, 371-382.

Clarke, N. E. (1941). The action of calcium on the human electrocardiogram. Amer. Heart J., 22, 367-373.

Cowgill, G. R., and Rakieten, T. L. (1930). The effect of intravenous injection of cal-ium lactate on gastric secretion. Amer. $J$. Physiol., 94, 165-169.

Del Castillo, J., and Katz, B. (1954). Quantal components of the end-plate potential. J. Physiol. (Lond.), 124, 560-573.

Donegan, W. L., and Spiro, H. M. (1960). Parathyroids and gastric secretion. Gastroenterology, 38, 750-759.

Ellison, E. H., Abrams, J. S., and Smith, D. J. (1959). A post mortem analysis of 812 gastroduodenal ulcers found in 20,000 consecutive autopsies, with emphasis on associated endocrine disease. Amer. J. Surg., 97, 17-30.

Fikry, M. E., and Dorry, K. (1964). The inhibiting action of parenteral calcium on gastric acid secretion in man. Acta gastro-ent. belg., 27, 172-178. 
Fillastre, J. P., Blaise, P., Bernier, J. J., and Richet, G. (1963). Effet de l'injection intraveineuse de gluconate de caleium sur la sécrétion gastrique. Presse méd., 715, 1738-1740.

Freedman, P., Moulton, R., and Spencer, A. G. (1958). The effect of intravenous calcium gluconate on the renal excretion of water and electrolytes. Clin. Sci., 17, 247-263.

Gill, J. R., Jr. and Bartter, F. C. (1961). On the impairment of renal concentrating ability in prolonged hypercalcaemia and hypercalciuria in man. J. clin. Invest., 40, 716-722.

Grant, R. (1941). The inhibition of gastric secretion by the intravenous injection of calcium salts. Amer. J. Physiol., 132, 460-466.

Gutman, A. B., Swenson, P. C., and Parsons, W. B. (1934). The differential diagnosis of hyperparathyroidism. J. Amer. med. Ass., 103, 87-94.

Hellström, J. (1959). Hyperparathyroidism and Gastroduodenal ulcer. Acta chir. scand., 116, 207-221.

Hoff, H. E., and Nahum, L. H. (1937). An analysis of the cardiac irregularities produced by calcium, and their prevention by sodium amytal. J. Pharmacol. exp. Ther., 60, 425-433.

Ivy, A. C., Grossman, M. I., and Bachrach, W. H. (1950). Peptic Ulcer, pp. 457-458, 475. Blakiston, Philadelphia.

Jones, F. A. (1959). Epidemiology of peptic ulcer in Great Britain with special reference to smoking. In Proceedings of the World Congress of Gastroenterology, vol. 1, pp. 19-24. Williams and Wilkins, Baltimore.

Mahfouz, M., and Koskowski, W. (1959). The effects of parenteral administration of calcium on gastro-intestinal secretions and hydrochloric acid formation. Arch. int. Pharmacodyn., 118, $1-11$
Martin, T. J., and Baird, C. W. (1965). Serum calcium determination by fluorometry. Med. J. Aust., 1, 463-465.

Murphy, D. L., Goldstein, H., Boyle, J. D., and Ward, S. (1966) Hypercalcaemia and gastric secretion in man. J. appl. Physiol. 21, $1607-1610$.

Ostrow, J. D., Blanshard, G., and Gray, S. J. (1960). Peptic ulcer in primary hyperparathyroidism. Amer. J. Med., 29, 769-779.

Ottenjann, R., Widmaier, F., and Demling, L. (1963). Hypercalcămie und Magensekretion. Klin. Wschr., 41, 717-719.

Payne, R. A., and Kay, A. W. (1962). The effect of vagotomy on the maximal acid secretory response to histamine in man. Clin. Sci., 22, 373-382.

Rogers, H. M., Keating, F. R., Jr., Morlock, C. G., and Barker, N. W. (1947). Primary hypertrophy and hyperplasia of the parathyroid glands associated with duodenal ulcer. Arch. intern. Med. 79, 307-321.

Sereghy, M., and Gyurkovich, T. (1927). Experimentelle Untersuchungen über die Einwirkung des Calciums auf die Sekretion und Motilitat des Magens. Z. Ges. exp. Med., 54, 271-276.

Smallwood, R. A. (1967). Some effects of intravenous calcium in man. Aust. Ann. Med., 16, 126-131.

St. Goar, W. T. (1957). Gastrointestinal symptoms as a clue to the diagnosis of primary hyperparathyroidism: a review of 45 cases. Ann. intern. Med., 46, 102-118.

Ward, J. T., Adesola, A. O., and Welbourn, R. B. (1964). The parathyroids, calcium, and gastric secretion in man and the dog. Gut., 5, 173-183. 